\title{
НАПРАВЛЕНИЯ РАЗВИТИЯ ФИНАНСОВЫХ ТЕХНОЛОГИЙ КАК АСПЕКТ ПРАВОТВОРЧЕСКОЙ ПОЛИТИКИ ЦЕНТРАЛЬНОГО БАНКА РОССИЙСКОЙ ФЕДЕРАЦИИ
}

\author{
(C) 2019 Голубитченко Мария Александровна \\ кандидат юридических наук \\ старший преподаватель кафедры финансового, банковского и таможенного права \\ Саратовская государственная юридическая академия \\ 410056, г. Саратов, ул. Вольская, д. 1 \\ E-mail: bearpaw-margo@yandex.ru
}

Кибер-атаки и мошенничество в финансовой сфере приносят огромный ущерб не только банковскому сектору, но и всей экономике России. В статье дана характеристика изданным Центральным банком РФ в инициативном порядке Основным направлениям развития финансовых технологий на период 2018-2020 годов как программного документа концептуального характера, в котором реализуется правотворческая политика Банка России в указанной сфере. Выделены два подхода законодателя к реализации нормотворческой функции Банка России: общий и специальный.

Обозначена тенденция развития нормотворческой функции Банка России, которая заключается в расширении специального подхода к определению нормотворческих полномочий Банка России, в том числе в сфере финансовых технологий. Дана положительная оценка нормотворческой активности Банка России и формирования делового взаимодействия регулятора с банковским сообществом в разработке механизма оценки последующего фактического воздействия нормативных актов Банка России.

Ключевые слова: Центральный банк РФ, финансовый рынок, финансовые технологии, Основные направления развития финансовых технологий, нормативные акты Банка России, правотворческая политика Банка России.

Развитие российского финансового рынка характеризуется активным внедрением финансовых технологий, что требует адекватного правового обеспечения. Е.Ю. Грачева справедливо обращает внимание на то, что финансовая сфера подвержена постоянным изменениям, обусловленным трансформацией финансово-правовых механизмов. Поэтому издание Центральным банком РФ Основных направлений развития финансовых технологий на период 2018-2020 годов является важным событием финансово-правового регулирования общественных отношений на финансовом рынке.

$\mathrm{B}$ «Стратегии экономической безопасности Российской Федерации на период до 2030 года», утвержденной Указом Президента РФ от 13 мая 2017 г. № 208, намечены цели и задачи государственной политики в сфере обеспечения экономической безопасности страны. Банк России, принимая во внимание вышеупомянутый документ, принял ряд мер для повышения уровня информационной безопасности проведения финансовых операций.
Эти инициативы ЦБ РФ изложены в Указе Банка России от 7 мая 2018 г. № 4793-У «О внесении изменений в положение Банка России от 9 июня 2012 года № 382-П «О требованиях к обеспечению защиты информации при осуществлении переводов денежных средств и о порядке осуществления Банком России контроля за соблюдением требований к обеспечению защиты информации при осуществлении переводов денежных средств» [1, с.58].

Целеполагание Основных направлений развития финансовых технологий на период 2018-2020 годов свидетельствует о системной направленности данного программного документа концептуального характера на эффективную реализацию функций Банка России на современном этапе социально-экономического и политико-правового развития.

Так, Банком России в Основных направлениях развития финансовых технологий на период 2018-2020 годов поставлены следующие цели: содействие развитию конкуренции на финансовом рынке; повышение доступности, качества и 
ассортимента финансовых услуг; снижение рисков и издержек в финансовой сфере; повышение уровня конкурентоспособности российских технологий.

Поэтому представляется весьма обоснованным подчеркнуть взаимосвязь Основных направлений развития финансовых технологий на период 2018-2020 годов с другим программным документом концептуального характера - Стратегией повышения финансовой доступности в России на период 2018-2020 годов, которая была одобрена Советом директоров Банка России 26 марта 2018 г.

Основные направления развития финансовых технологий на период 2018-2020 годов содержат положения о необходимости издания нормативных правовых актов в заявленной сфере общественных отношений, включая нормативные акты Банка России. Обозначенный программный документ Банка России, носящий концептуальный, стратегический характер, содержит элементы концепции проекта нормативного акта Банка России.

В указанном аспекте Основные направления развития финансовых технологий на период 2018-2020 годов возможно охарактеризовать как документ правотворческой политики Центрального банка РФ, что представляется актуальным исследовать как с научно-теоретических, так и с практических позиций.

В теории права нормативные правовые акты федеральных органов исполнительной власти подвергаются анализу не только с позиций устранения подзаконного правотворчества, вытеснения его законодательным регулированием, но и, что представляется востребованным, с позиций изменения политики в отношении этого вида правотворческой деятельности, сутью которого являются гармонизация законодательства; определение его меры и удельного веса, которые не должны вести к исчезновению подзаконного (в том числе ведомственного) регулирования; создание необходимых условий для оптимального сочетания законов и подзаконных актов в правовой системе страны.

Как справедливо полагают А.В. Малько и А.П Мазуренко, это объясняется тем, что в законах невозможно полностью отразить все тонкости регулирования тех или иных общественных отношений; развивать и конкретизировать положения законов призваны подзаконные акты, в которых содержится самая значительная часть всех правовых предписаний [5, с.95].

Это касается и правотворчества Центрального банка РФ как субъекта с особым публично-правовым статусом, нормотворческая функция которого последовательно рассматривается Конституционным Судом РФ как элемент компетенции Центрального банка РФ, имеющей конституционно-правовые основы. В определении от 26 октября 2017 г. № 2494-О «Об отказе в принятии к рассмотрению жалобы гражданина Давыдова Андрея Павловича на нарушение его конституционных прав частью первой статьи 7 Федерального закона "О Центральном банке Российской Федерации (Банке России)” К Конституционный Суд РФ подтвердил ранее сформулированные правовые позиции о нормотворческих полномочиях Банка России, характеризующихся принципом обязательности.

Следует подчеркнуть, что в деятельности правотворческих органов важное значение имеет принцип гласности. В указанном аспекте позитивное значение приобретает факт размещения Основных направлений развития финансовых технологий на период 2018-2020 годов на главной странице официального сайта Банка России в информационно-телекоммуникационной сети Интернет [3, с.209].

Применительно к Основным направлениям развития финансовых технологий на период 2018-2020 годов следует выделить два подхода в реализации нормотворческой функции Центрального банка РФ: общий и специальный. Общий подход в определении полномочий Центрального банка РФ на издание нормативных актов закреплен в ст. 7 Федерального закона «О Центральном банке Российской Федерации (Банке России)», что имеет отношение и к изданию Банком России нормативных актов в сфере финансовых технологий.

Специальные подходы определены в проектах федеральных законов № 419059-7 Ф3 «О цифровых финансовых активах»8, который предусматривает издание Банком России нормативных актов как самостоятельно, так и по согласованию с Правительством РФ, и № 419090-7 «Об альтернативных способах привлечения инвестиций (краудфандинге)», который четко формулирует позицию о полномочиях Банка России принимать нормативные акты по вопросам, отнесенным к его компетенции настоящим федеральным законом (п. 7 ч. 1 ст. 14 проекта).

Усиление специального подхода в реализа- 
ции нормотворческой функции Банка России является тенденцией развития правового регулирования нормотворческой функции Банка России, в том числе применительно к вопросам правового регулирования финансовых технологий.

Правовое регулирование финансовых технологий содержит финансово-правовую, административно-правовую, гражданско-правовую и иную отраслевую направленность. Издание нормативных актов Банка России в сфере развития финансовых технологий ставит вопрос о полномочиях Банка России издавать нормативные акты, содержащие нормы гражданского права.

Дело в том, что ст. 3 Гражданского кодекса РФ, закрепляя подзаконное нормотворчество в сфере гражданских отношений, обращает внимание на полномочия Президента РФ, Правительства РФ, министерств и иных федеральных органов исполнительной власти, к которым Центральный банк РФ не может быть отнесен в силу особенностей публично-правового статуса.

Выходом из сложившейся ситуации предлагается считать положения ч. 4 ст. 48 ГК РФ о том, что правовое положение Центрального банка РФ (Банка России) определяется Конституцией РФ и законом о Центральном банке РФ, т.е. включая полномочия на издание нормативных актов, в том числе содержащих нормы гражданского права.

В перспективе представляется необходимым внести дополнение в ст. 3 ГК РФ о нормативных актах Банка России, содержащих нормы гражданского права. Следует заметить, что проект Федерального закона № 424632-7 «О внесении изменений в части первую, вторую и четвертую Гражданского кодекса Российской Федерации» не содержит упоминаний о нормативных актах Банка России.

Возможно суждение и о том, что упоминаемые в проектах федеральных законов № 419059-7 «О цифровых финансовых активах» и № 419090-7 Ф3 «Об альтернативных способах привлечения инвестиций (краудфандинге)» нормативные акты Банка России не будут содержать нормы гражданского права, а будут являться источниками финансового права, административного права.

В указанном аспекте заслуживает поддержки предложение о выделении для целей оценки качества нормативных правовых актов федеральных органов исполнительной власти, нор- мативных правовых актов Центральной избирательной комиссии РФ, нормативных актов Банка России, нормативных правовых актов иных государственных органов Российской Федерации и должностных лиц Российской Федерации.

Таким образом, нормативные акты Банка России справедливо предлагается рассматривать обособленно от нормативных правовых актов федеральных органов исполнительной власти. Изложенный подход предлагается использовать при внесении дополнений в ст. 3 ГК РФ о нормативных актах Банка России, содержащих нормы гражданского права.

Подлежат доктринальному осмыслению новеллы правового регулирования нормотворческой функции Банка России, предусмотренные в Положении Банка России от 22 сентября 2017 г. № 602-П «О правилах подготовки нормативных актов Банка России», касающиеся планирования нормотворческой деятельности Банка России, оценки регулирующего воздействия нормативных актов Банка России применительно к реализации Основных направлений развития финансовых технологий на период 2018-2020 годов.

В указанном аспекте представляется важным развитие взаимодействия Банка России и банковских ассоциаций. Заслуживает внимания позиция Президента Ассоциации банков России (Ассоциации «Россия») Г.И. Лунтовского, который в докладе на XX Всероссийской банковской конференции «Банковская система России 2018: практические вопросы текущего надзора и регулирования» обратил внимание на то, что Ассоциация планирует выйти с инициативой и предложить Банку России механизм оценки последующего фактического воздействия нормативных актов.

Это имеет отношение и к оценке последующего фактического воздействия нормативных актов Банка России в сфере финансовых технологий. Нормотворческая активность Банка России востребована в связи с развитием общественных отношений в сфере финансовых технологий. Нормотворческая активность Банка России носит позитивный характер. Следует согласиться с высказанным в науке мнением о рассмотрении реализации правотворческих функций как проявлении культуры организации юридического процесса.

В юридической науке обсуждается проблема бездействия в правотворчестве и законода- 
тельном процессе в общетеоретическом аспекте. 2020 годов являются инициативно изданным Для науки финансового права данные вопросы также актуальны.

Центральным банком РФ программным документом концептуального характера, выражаю-

Таким образом, Основные направления раз- щи правотворческую политику Банка России в вития финансовых технологий на период 2018- указанной сфере.

\section{Библиографический список}

1. Белов В. М., Зырянова Е.В., Косов Д.Л. Особенности оценки качества нормативных правовых актов. Использование автоматизированной системы оценки качества нормативных правовых актов // Государство и право. - 2017. - № 10 .

2. Гневко А. В., Макроменко В.Д. Бездействие в правотворчестве и законодательном процессе: общетеоретический аспект // Ленинградский юридический журнал. - 2017. - № 3.

3. Комиссаров E. А. Тенденции развития угроз информационной безопасности // Образование и наука без границ: социально-гуманитарные науки, 2016. № 3. С. 209.

4. Литвинов Д.А. Киберпреступность в банковской сфере России: характер, масштабы, последствия // Преступность в сфере информационных и телекоммуникационных технологий: проблемы предупреждения, раскрытия и расследования преступлений. Воронеж, 2017. № 1. С. 38.

5. Малько А. В., Мазуренко А.П. Правотворческая политика России: история и современность: монография.М.: Юрлитинформ, 2014.

6. Трофимов В. В., Самородов В.Ю. Реализация правотворческих функций как проявление культуры организации юридического процесса // Правовая парадигма. - 2017. - Т. 16. - № 4. 